\title{
高齢者における交通事故の特徵と心理状態の検証
}

\author{
○矢島潤平 · 大嶋美登子 \\ (別府大学文学部人間関係学科)
}

Key words:高齢者，交通事故，判断能力

\section{（目 的）}

現在, 高齢者の関わった交通事故増加が問題視されている. 西田（2004）は，最近の高齢者の交通事故の増加が著明であ り，特に運転中の死傷者や人身事故の第一当事者数の伸びが 大きいことを明らかにした。

我々は，高齢運転者を対象に，高齢者講習時に交通安全に 関する調査を行い，自分の運転に自信を持っており，交通ル 一ルもしっかり守っているという意識が強いことを明らかに した（別府大学交通安全問題研究会，2006）.

本研究では，実際に事故に遭遇した高齢者の事故の特徵を 明らかにするとともに，交通事故予防への提言も検討するこ とを目的とした。大分県内で発生した交通事故に遭遇した者 を対象として，道路や標識などの環境面，事故の特徵や損傷 の状態などの事故の影響面，事故当事者の認知的判断能力な ど総合的に検証した.

\section{（方 法）}

対象と手続き： 2006 年 1 月 1 日から 12 月 31 日までに大分 県内で発生した交通事故のデータを対象とした。年齢が 65 歳以上の高齢者群 (男 1292 , 女 869, 年齢 72.7 0 0.1) と 18-50 歳までの若年者群（男 5266，女 4187，年齢 $32.2 \pm 0.1 ）$ の 2 群について比較分析を行った. 高齢者群の免許歴は 10 年以上 が多くを占めていた $(97.5 \%)$. 高齢者は退職後の買い物，訪 問，通院，業務目的，散歩，観光時に事故に遭遇していた. 分析項目：遭遇した事故内容（死亡者，重傷者及び軽傷者）, 事故発生時間帯 (昼と夜), 事故発生時の天候（晴，雨など）, 事故が発生した地形（市街地や非市街地など），路面状態（乾 燥や非舖装時など)，信号機の形態(信号機があるないなど)， 事故類型（人対車両，車両相互及び車両単独），一時停止（拡 大反射式や一時停止なしなど)，危険認知（停止中や $40 \mathrm{~km} / \mathrm{h}$ 以下など), 事故時の損傷主部位（頸部や全損など）及び事故 の損傷状態 (骨折や内臓破裂など).

\section{(結 果と考 察)}

遭遇した事故内容については，高齢者は死亡者が発生した 事故への遭遇率が最も高かった（表 1 )。高齢者が事故に遭遇 すると軽傷ではすまず死亡や重傷を負う可能性が非常に高い ことを示唆している.

事故発生の時間帯については，高齢者は，日中の事故の割 合が高く，夜間の事故は低かった．事故発生時の天候につい ては，高齢者は，晴天時の事故の割合が高かった。事故が発 生した地形については，高齢者は，市街地では低かったが， 非市街地では高かった。路面状態については，高齢者は，路 面が乾燥している時と非舗装時に高かったが，湿潤時の場合 は低かった。ほとんどの高齢者は退職しており，主に尽に運 転しており，運転条件の悪い夜間や悪天候下や道路環境の悪

\section{表 1 高齢者と若年者の遭遇した事故内容の比較}

\begin{tabular}{lcccc}
\hline & \multicolumn{2}{c}{ 高 齢 者 } & \multicolumn{2}{c}{ 若 年 者 } \\
& $\mathrm{N}$ & $(\%)$ & $\mathrm{N}$ & $(\%)$ \\
\hline 死亡 & 953 & $(44.1)$ & 4430 & $(46.9)$ \\
重傷 & 865 & $(40.0)$ & 3844 & $(40.7)$ \\
軽傷 & 343 & $(15.9)$ & 1179 & $(12.5)$ \\
\hline
\end{tabular}

いところでの運転を意識的に避けていることが示唆される. 事故発生地形では, 高齢化が進む人口規模の小さな地域では, 公共の交通機関が整備されておらず，高齢者が自ら運転する 機会が多いために非市街地の事故が多いと考えられる.

事故類型については，人対車両の事故で高齢者は，横断中 や路上停止中の事故の割合が高かった. 車両相互の事故では, 高齢者が出会頭や追い越しの事故の割合が高く，追突事故は 低かった（表 2 ）. 車両単独の事故では，高齢者が電柱や家屋 への衝突事故や転落・転倒の事故の割合が高かった，高齢者 はスピードを出しすぎず慎重に運転しているということがう かがえる. 高齢者の主道路への進入に対する躊躇や追い越し 時の判断の鈍さが影響していることが示唆される.

一時停止については，高齢者は，標識があるところでは一 旦止まっているが，標識がないところでは停止していなかっ た. 寸なわち, 高齢者は標識に依存しており, 標識のない場 所では安全を心掛けていないことが示唆される.

危険認知については，高齢者は，停止中及び $40 \sim 70 \mathrm{~km} / \mathrm{h}$ 以下では低く, $20 \mathrm{~km} / \mathrm{h}$ 以下では高かった．高齢者で最も多か った事故の一つに出会い頭での衝突事故がある。これらの知 見から，停止中の危険認知が低いことが出会頭での衝突へと 繋がっており，停止中に対する何らかの注意喚起が必要であ ることが示唆される．以上のことから，事故を起こすという 危機感や起こる前の瞬時に危険を判断することは若年者より もかなり悪い条件がそろっていることが示唆される.

高齢者は事故に遭遇してしまうという考えにまでは至らず, 自分自身が安全運転をしているから事故には遭わないだろう という確信を持っていることが推測された.危険認知の低下， 自体防衛の脆弱性などから, 事故に遭った時に柔軟な対応を 判断できず，事故認識を持てないという特徴を持っているこ とが示唆される.

高齢者の交通事故の死亡数を減らすために，歩行中の左右 確認や注意集中などの安全教育，運転者に対して高齢歩行者 の注意不足に伴う行動の理解などを教育することが必要であ る。例えば，大分県警察は一つの取り組みとして声かけ運動 等を行っている.このような警察官や地域の住民の地道な活 動が事故軽減につながっている。

\section{（引用文献）}

別府大学交通安全問題研究会 2006 高齢者の行動傾向 交 通事故防止の視点から

西田 泰（2004）高齢者の安全教育のあり方について（第 2 報)，警察学論集，57，12，157-172

本研究は, $\mathrm{H} 18$ 年度大分県交通安全協会委託研究より補助を 受けた

表 2 高齢者と若 年 者の事 故 類 型

\begin{tabular}{lcccc}
\hline & \multicolumn{3}{c}{ 高 齢 者 } & \multicolumn{3}{c}{ 若 年 者 } \\
& $\mathrm{N}$ & $(\%)$ & $\mathrm{N}$ & $(\%)$ \\
\hline 正 面 衝 突 & 91 & $(4.2)$ & 376 & $(4.0)$ \\
追 突 & 610 & $(28.2)$ & 4594 & $(48.6)$ \\
出会い頭 & 569 & $(26.3)$ & 1699 & $(18.0)$ \\
追い抜き & 48 & $(2.2)$ & 108 & $(1.1)$ \\
\hline
\end{tabular}

(YAJIMA Jumpei, OSHIMA Mitoko) 